\title{
The effect of Herbicides on Residual Effects of Atrazine under Conservation Agriculture
}

\section{Mutsvandiani Chikutuma ${ }^{1,2}$, Tembo Lovejoy ${ }^{1}$ and Kurangwa Wisdom ${ }^{1 *}$}

\author{
${ }^{1}$ Zimbabwe Open University1, Faculty of Agriculture, P. O. Box MP1119, Mount Pleasant \\ Harare Zimbabwe. \\ ${ }^{2}$ Hatcliffe Institute of Agricultural Engineering2, P. O. Box BW 338 Borrowdale, Hatcliffe, \\ Harare, Zimbabwe.
}

Article No.: 082914341

DOI: 10.15580/GJAS.2015.2.082914341

Submitted: $29 / 08 / 2014$

Accepted: $22 / 03 / 2015$

Published: $27 / 03 / 2015$

${ }^{*}$ Corresponding Author

Kurangwa Wisdom

E-mail: wkurangwa@gmail.com

\section{Keywords:}

conservation agriculture, atrazine, cowpea, residual effect
An experiment was set up to evaluate the residual effect of atrazine in cowpea production under conservation agriculture. The trial was superimposed on a previous herbicide trial of a maize crop in 2012/2013 season. The experiment was laid out in a randomized complete block design with three replicates and four treatments as follows; 1 . control (manual weeding), 2. Atrazine (3.6 litres/ha), 3. Atrazine (3.6 litres/ha) + glyphosate (2.5 litres/ha) and 4. Atrazine (3.6 litres/ha) + glyphosate (2.5 litres/ha) + metolachlor (1 litre/ha). Herbicide treatment was carried out at planting time and manual weeding at $10 \mathrm{~cm}$ weed height. Data collected include: germination percentage, weed counts and weed biomass, cowpea biomass, pod length and cowpea yield. The herbicidal treatments showed a significant effect $(p<0.05)$ on pod length and cowpea yield. The control plot had the highest pod length of $17.03 \mathrm{~cm}$ and atrazine alone had the least of $15.77 \mathrm{~cm}$. A combination of three herbicides had the highest yield of $1.2 \mathrm{t} / \mathrm{ha}$ and atrazine alone had the lowest yield of $0.9 \mathrm{t} / \mathrm{ha}$. No significant $(p>0.05)$ effects were recorded on percentage germination, weed counts and weed biomass as well as on cowpea biomass. Tank mixing of two or more herbicides is recommended when using atrazine to reduce residual effect and further research is recommended under different soil types with different climatic conditions. 


\section{INTRODUCTION}

In Zimbabwe smallholder farmers occupy 1.6 million hectares of the country and their average maize (Zea mays L) yield is $0.8 \mathrm{t} / \mathrm{ha}$ (Baudron et al., 2012). The low maize yields are a result of increased rate of natural resources degradation (Munodawafa, 2012). Farmers have relied on the use of mouldboard ploughs and hand hoes for land preparation since 1920 (Johansen et al., 2012). The side effects of tillagebased agriculture practices without sufficient organic matter inputs has led to land degradation and soil erosion that can be as high as 12 tonnes per hectare in many parts of the country leading to decline in productivity and food insecurity (Wall 2007; Thierfelder and Wall, 2009). Crop production in Zimbabwe is also adversely affected by uneven rainfall distribution due to climate variability (Niggol et al., 2009). Promotion of more sustainable agricultural systems with potential to reduce the effects of soil degradation and climate change will improve the livelihoods of smallholder farmers. Conservation agriculture is one of the systems currently proposed to reduce the impacts of climate change and land degradation (Lal et al., 2011).

Food and Agricultural Organization of the United Nations (2002), describes conservation agriculture as 'a way of farming that conserves, improves and makes more efficient use of natural resources through integrated management of the available resources combined with external input. It is based on three basic principles of minimum soil disturbance, maintenance of a permanent soil cover through residue retention and/or the use of green manure cover crops and crop rotations. Reduced tillage under conservation agriculture prevents soil inversion that exposes buried weed seeds to the soil surface where conditions are favourable for germination. More weed seeds will accumulate on or near the surface (Ghosheh and Al-Hajaj, 2005), where there are likely to germinate in one season and highly exposed to predation. The weed seed bank can be depleted through weeding of all emerged weeds before they set seed. However, due to minimum soil disturbance in conservation agriculture, there is a change in weed flora from broadleaved weeds to perennial grasses (Derpsch, 2008). Retention of residues under conservation agriculture hinders manual weeding that can lead to difficulties in depleting the weed seed bank. Use of herbicides to improve weed management practices under conservation agriculture has been promoted. In Zimbabwe, the commonly used herbicides are; atrazine, glyphosate, paraquat and dual. Atrazine, which is commonly used in maize systems, is a preemergent photosynthetic inhibitor of broadleaf weeds that has been reported to injure vegetative crops from previous herbicide application (Peyvastegan and Farahbakhsh, 2011). It has long herbicide residual effects and its persistence is dependent on soil type
(Croplife, 2006) hence; it may affect crop rotations especially if broadleaved crops are included.

Soil composition affects herbicide phytotoxicity and persistence through adsorption, leaching, and volatilization (Croplife, 2006). Generally, soils high in clay, organic matter, or both have a greater potential for herbicide carryover because there is increased adsorption to soil colloids, with a corresponding decrease in leaching and volatilization losses (Aaron et al. 2007). Therefore, more herbicide is held in reserved form to be released later, potentially injuring susceptible future crops. Reduced doses of atrazine and improved microbial activity can promote faster atrazine degradation (Krutz et al., 2009) which may reduce atrazine carry over problems in rotations with broadleaved crops under conservation agriculture. Thus, change of micro environment under conservation agriculture may contribute to faster degradation of atrazine making it ideal under conservation agriculture practices. Research has shown that chemical weed control options are more effective than manual weeding under conservation agriculture (Vogel, 1994; Rugare, 2009 Muchineripi, 2010). Thus, this research seeks to analyse the residual effect of atrazine on cowpea under conservation agriculture.

\section{MATERIALS AND METHODS}

\section{Experimental site}

The experiment was conducted at the Institute of Agricultural Engineering (IAE) which is located $21 \mathrm{~km}$ north-west of the city of Harare, along Harare Domboshava road. The site has a grid reference of $17^{\circ}$ $42^{\prime} \mathrm{S}$ and $31^{\circ} 06^{\prime} \mathrm{E}$ and an altitude of $1500 \mathrm{~m}$ above sea level (Machekano et al., 2012). IAE is characterised by deep well drained soils classified as Chromic Luvisols and these soils have more than $60 \%$ clay content and falls under agroecological region (II) of Zimbabwe (Nyamapfeni,1991). The annual rainfall experienced during the period of the experiment in the area ranged between 750 and $1000 \mathrm{~mm}$ per annum with most of the rain falling between the month of November and March. The mean annual temperature ranged between 15 to $30{ }^{\circ} \mathrm{C}$, during the same period (Muzemu et al., 2011).

\section{Experimental design and treatments}

The experiment was laid out as a randomised complete block design (RCBD) with four treatments replicated three times. Each plot had a gross size of $37.8 \mathrm{~m}^{2}$ and a net plot of $24 \mathrm{~m}^{2}$ with a spacing of $0.45 \mathrm{~m}$ between the rows and $0.15 \mathrm{~m}$ within the row. This experiment was superimposed on the plots where maize was grown using herbicides under the 20122013 season with the treatments shown in table 1 below. 
Table 1: Treatments that were used under maize weed control strategy

\begin{tabular}{|l|l|}
\hline Treatment & Weed control strategy \\
\hline Control & Manual weeding at $10 \mathrm{~cm}$ weed height. \\
\hline Atrazine & $\begin{array}{l}\text { Application of } 3.6 \text { litres } / \text { ha of atrazine at planting time }+ \text { manual weeding at } 10 \mathrm{~cm} \text { weed } \\
\text { height. }\end{array}$ \\
\hline $\begin{array}{l}\text { Atrazine }+ \\
\text { Glyphosate }\end{array}$ & $\begin{array}{l}\text { Application of } 2,5 \text { litres } / \text { ha of glyphosate }+3.6 \text { litres } / \text { ha of atrazine at planting time }+ \\
\text { manual weeding at } 10 \mathrm{~cm} \text { weed height. }\end{array}$ \\
\hline $\begin{array}{l}\text { Atrazine }+ \\
\text { Glyphosate } \\
+ \text { Dual }\end{array}$ & $\begin{array}{l}\text { Application of } 2,5 \text { litres } / \text { ha of glyphosate }+3.6 \text { litres } / \text { ha of atrazine }+1 \text { litre/ha of metolachlor } \\
\text { at planting time }+ \text { manual weeding at } 10 \mathrm{~cm} \text { weed height. }\end{array}$ \\
\hline
\end{tabular}

\section{Trial management}

Maize residues were uniformly spread in each plot at a rate of 2.5 tonnes per ha after marking the plots. Cowpea crop cultivar CBC2 was used in the experiment. A ripper was used to open up the furrows for planting. Planting was carried out with the first effective rains. A basal fertilizer of compound D (N7: P14: K7) was applied at $200 \mathrm{~kg}$ per ha and no nitrogen top dressing was applied because cowpea has the potential to fix nitrogen (Bohlool, et al, 1992). The plots were kept weed free by hand hoeing. Aphid incidences were controlled with carbaryl $85 \%$ WP. Hand harvesting of the crop was carried out at 12 weeks after planting.

\section{Data collection}

Germination percentage was recorded at $50 \%$ emergence. Above ground biomass was collected in each plot every fortnight by destructive sampling. Ten cowpea plants were randomly cut at ground level from each plot weighed for fresh weights. These were then oven dried at $80^{\circ} \mathrm{C}$ for 48 hours to obtain dry weight. Weed counts and weed biomass were taken prior to each weeding operation. Quadrat sampling $(0.5 \mathrm{~m} \times$ $0.5 \mathrm{~m}$ ) was used to determine species composition. Four quadrants were randomly selected from each plot. A sample of five pods was randomly selected from each plot for recording pod length. The cowpeas were harvested from the net plot and allowed to dry under the open sun. Shelling of the cowpea was done and the grain weight was recorded.

\section{Data Analysis}

Analysis of variance was carried out using Genstat version 12 and mean separation was done using the least significant differences at 0.05 probability level.

\section{Statistical Analysis}

Analysis of variance was carried out using Genstat version 12 and mean separation was done using the least significant differences at 0.05 probability level to determine treatments on cow pea percentage germination, pod length, weed counts and weed biomass, cow pea biomass and cow pea yield.

\section{RESULTS AND DISCUSSION}

\section{Percentage Germination}

There was no significant difference among the treatments $(p>0.05)$ in percentage germination of cowpea. At germination, atrazine residue had not yet affected the cowpea. These results concur with the results obtained by Taber (2009) on his work on sweet corn-snap beans rotations where emergence and early growth of snap beans were not affected by residual herbicide. 


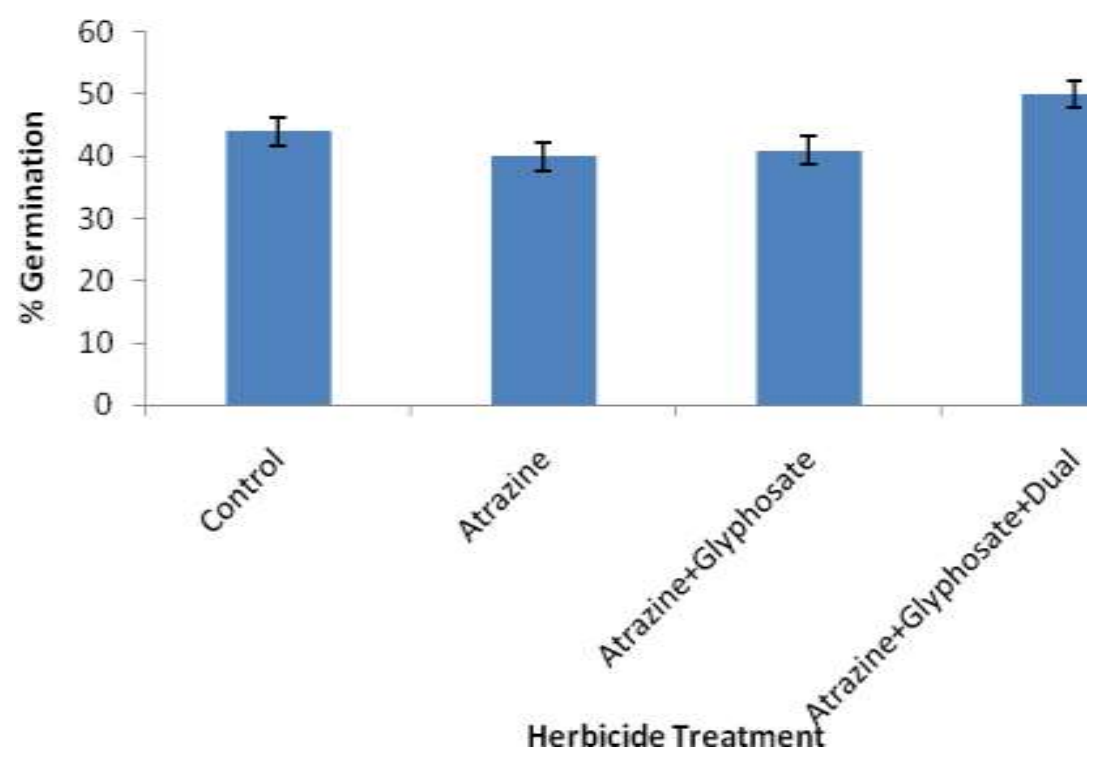

Figure 1: Effect of residual herbicide on germination of cowpea Vertical bars represent standard error bars of means

\section{Effect of herbicide on pod length}

A significant difference $(p<0.05)$ was observed among treatments with respect to pod length. The control treatment had the highest pod length of $17,03 \mathrm{~cm}$ because there was no herbicide applied to it and therefore the cowpea was not affected. Atrazine alone had the least pod length of $15.77 \mathrm{~cm}$ (Figure 2). This is because when atrazine is applied alone it tends to have more residual effect on the crop (Reinhardt, 1995). Moreover, no significant effect $(p>0.05)$ between control and a combination of three herbicides was observed. The three treatments with herbicides showed no significant differences among themselves (Figure 2). This is because having been established in clay soils (Nyamapfene, 1991) under conservation agriculture there is high herbicide adsorption (Süzer and Büyük, 2010). There was no significant effect between the control treatment and a combination of three herbicides $(p>0.05)$. This is because tank mixing two or more herbicides reduces the residual effect of atrazine (Aaron et. al .2007; Djumalieba and Vassilev, 1993).

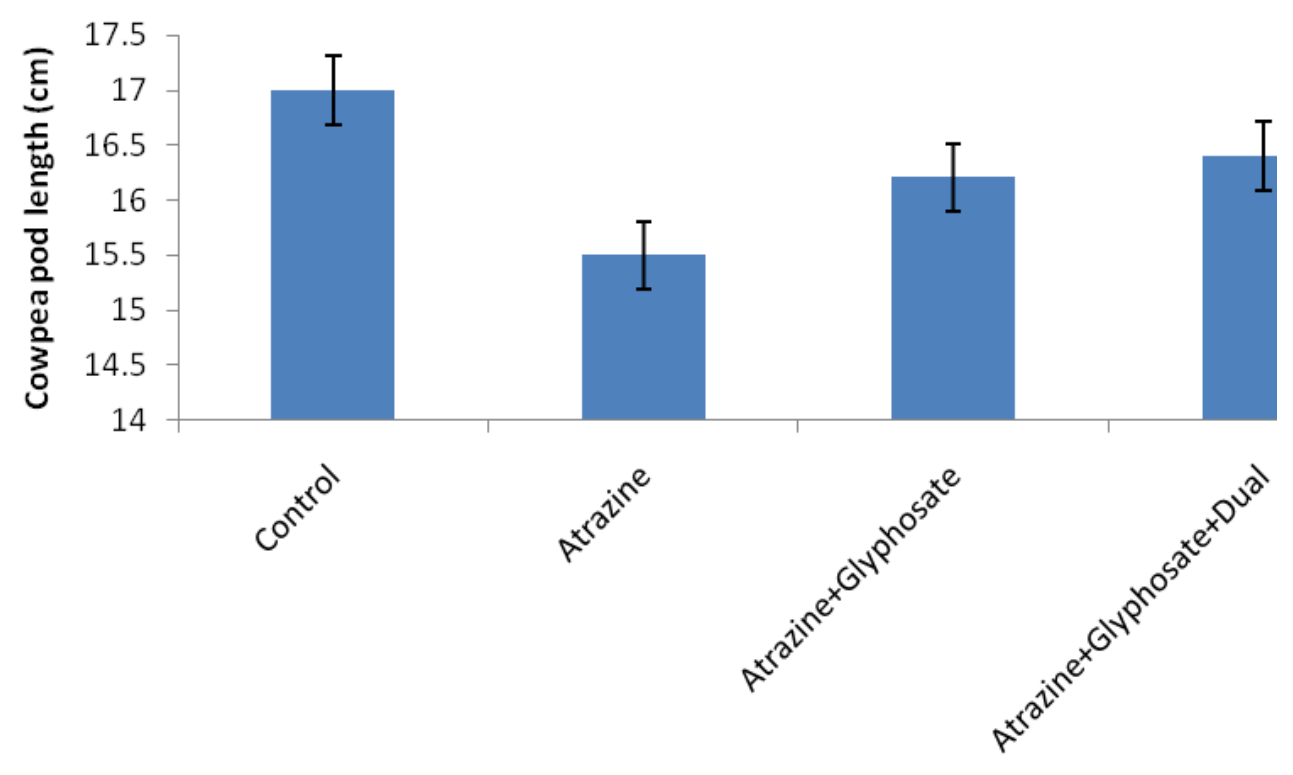

Herbicide Treatment

Figure 2: The effect of herbicide on pod length of cowpea

Vertical bars represent standard error bars of means 


\section{Weed counts and weed biomass}

There was also no significant difference among treatments $(p>0.05)$ with respect to weed counts and weed biomass. These results concur with results obtained by Verma et al, (2009) on their work on maize-green-gram cropping systems.

\section{Cowpea biomass}

The residual herbicide showed no significant effect on cowpea biomass $(p>0.05)$ in each week. The above normal rains received during the 2013/2014 season reduced the effect of herbicide carryover (Esterhuizen, 2014). Constantly moist soil and excessive rainfall might have promoted herbicide breakdown or leaching below the crop root zone.

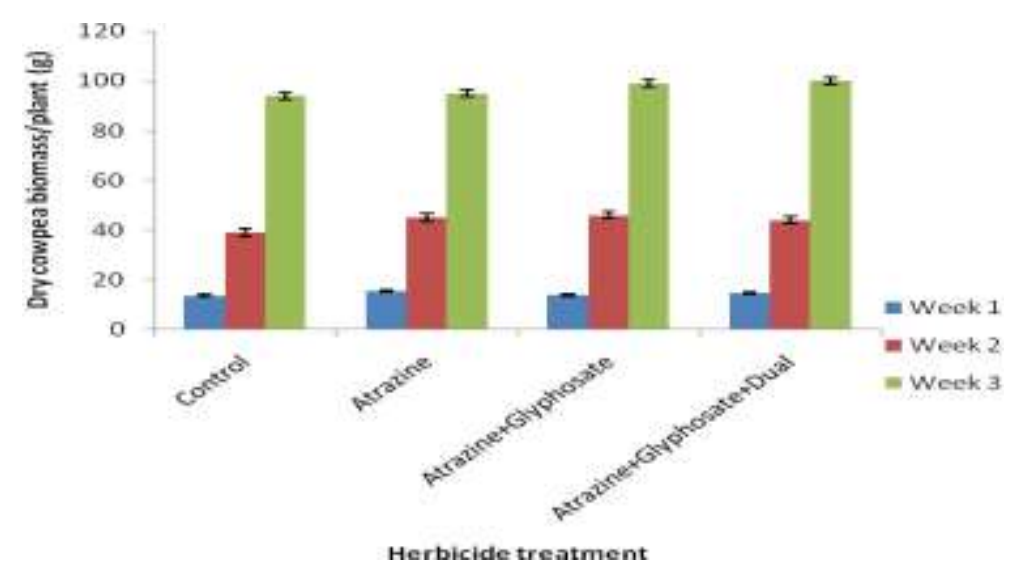

Figure 3: Effect of residual herbicide on fresh and dry cowpea biomass Vertical bars represent standard error bars of means

\section{Effect herbicide on cowpea yield}

A significant effect of herbicide on cowpea yield was observed $(p<0.05)$. Atrazine had the lowest yield of 0.9 t/ha (Figure 4). When atrazine is applied alone it tends to have a residual effect on the successive crop (Reinhardt, 1995). A combination of three herbicides had the highest yield of $1.2 \mathrm{t} / \mathrm{ha}$ but no significant differences were observed between a combination of three herbicides and control plot. This could be because tank mixing two or more herbicides reduces the residual effect. Hager and Nordby, (2007) observed that by tank mixing two or more herbicides, the residual effect of atrazine is reduced. A combination of two herbicides and a combination of three herbicides showed significant effects $(p<0.05)$ after mean separation. This could be because the additional herbicide further reduced the residual effects of atrazine.

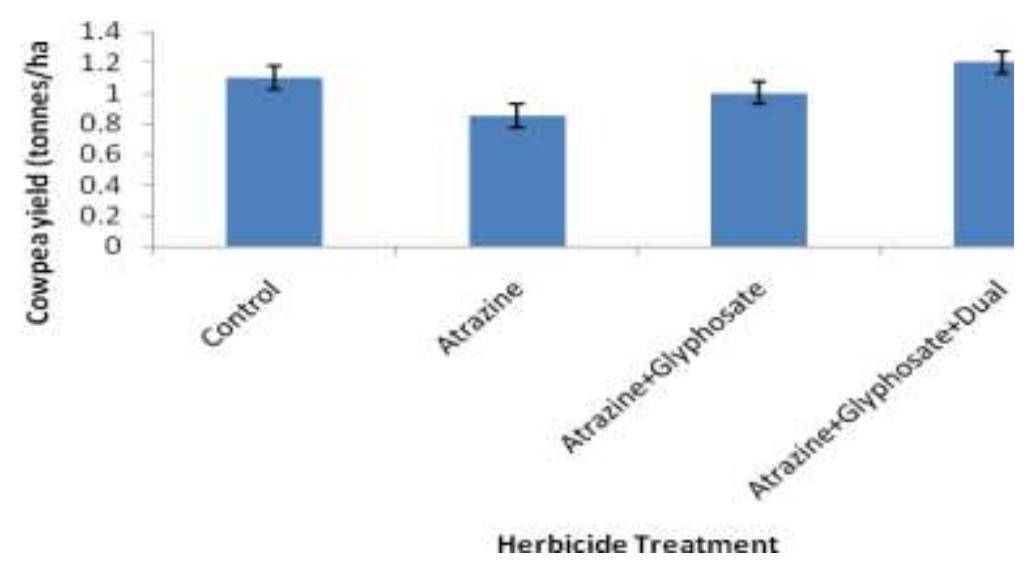

Figure 4: The effect of herbicide on cowpea yield

Vertical bars represent standard error bars of means 


\section{CONCLUSION}

Germination of cowpea was not affected by the residual atrazine. Cowpea growth was not affected by the residual atrazine however; yield of cowpea was significantly affected. The control treatment had the highest pod length with the lowest pod length obtained from atrazine. A combination of three herbicides had the highest yield due to breakdown of atrazine induced by tank mixtures. Residual effects of herbicide were noted in Atrazine when applied alone and this resulted in lowest yields. Weed biomass and cowpea biomass were also not affected by the residual atrazine as the atrazine could have been leached beyond the rooting zone.

\section{ACKNOWLEDGEMENT}

The first author would like to thank the Hatcliffe Institute of Agricultural Engineering for their support during this study. This work was carried out as part of Hatcliffe Institute activities in Zimbabwe.

\section{REFERENCES}

Baudron, F., Tittonell, P., Corbeels, M., Letourmy, P. and Giller, K. E. (2012). Comparative performance of conservation agriculture and current smallholder farming practices in semi-arid Zimbabwe. Field Crops Research 132: 117-128.

Bohlool, B. B., Ladha, J. K., Garrity, D. P. and George, T. (1992). Biological nitrogen fixation for sustainable agriculture: A perspective Plant and Soil 141: 1-11, 1992.

Croplife (2006). Zimbabwe Croplife Chemical Handbook. Volume 2: Herbicides. Harare.

Derpsch, R. (2008) No-tillage and conservation agriculture: A progress report. In No-till farming systems, Vol. 3 (Eds T. Goddard, M. Zoebisch, Y. Gan, W. Ellis, A. Watson and S. Sombatpaint). Paraguay: Special Publications.

Djumalieva, D. and Vassilev, A. (1993). Cropping Systems in Intensive Agriculture, M.D. Publications Pvt. Ltd, ISBN 8185880077, 9788185880075 pp214

Esterhuizen, D. (2014) Grain and feed annual report, USDA Foreign Agricultural Services,

Global Agricultural Information Network http://gain.fas.usda.gov/Recent\%20GAIN\%20/Publ ications/Grain\%20and\%20feed\%20annual\%20rep ort_Pretoria_Zimbabwe_7-17-2014.pdf

FAO, (2002). Conservation agriculture: Case studies in Latin America and Africa. In FAO Soils Bulletin, Vol. 78 Rome: FAO.

Ghosheh, H. and Al-Hajaj, N. (2005). Weed seedbank response to tillage and crop rotation in a semi-arid environment, Soil and Tillage Research 84 (2): 184-191

Hager, A. G. and Nordy, D. (2007). Herbicide persistence and how to test for residues in soils.
Illinois Agricultural Pest Management Handbook 344 pp333-350.

Johansen, C., Haque, M. E., Bell, R. W., Thierfelder, C. and Esdaile, R. J. (2012). Conservation agriculture for small holder rainfed farming: Opportunities and constraints of new mechanized seeding systems. Field Crops Research 132(0): 18-32.

Krutz, J. L., Shaner, D. L., Weaver, M. A., Webb, R. M. T., Zablotowicz, R. M., Reddy, K. N., Huanga, Y. \&Thomsona, S. J. (2009). Agronomic and environmental implications of enhanced s-triazine degradation. Wiley Interscience 66: 461-481.

Lal. R., Delgado, J. A., Groffman, P. M., Millar, N., Dell, C. and Rotz, A. (211). Management to mitigate and adapt to climate change, Journal of Soil and Water Conservation vol. 66 (4): 276285.

Machekano, H., Mvumi, B. M. and Rwafa, R. (2012). Temporal population dynamics of storage insect pests and their management using safer grain protectants in maize smallholder systems of Zimbabwe. Third RUFORUM Biennial Meeting 24 28 September 2012, Entebbe, Uganda.

Muchineripi, G. (2010). Evaluation of the efficacy and economics of different weed control strategies. In Crop Science, Vol. Masters of Science: Africa University, Zimbabwe.

Munodawafa, A. (2012) "The Effect of Rainfall Characteristics and Tillage on Sheet Erosion and Maize Grain Yield in Semiarid Conditions and Granitic Sandy Soils of Zimbabwe," Applied and Environmental Soil Science, vol. 2012, Article ID 243815, 8 pages, 2012. doi:10.1155/2012/243815

Niggol, S. S., Dinar, A., Hassan, R. and Kurukulasuriya, P. (2009). A ricardian analysis of the distribution of climate change impacts on agriculture across agro-ecological zones in Africa. Springer 43: 313-332.

Nyamapfeni, K. (1991). Soils of Zimbabwe Nehanda Publishers

Muzemu, S., Mvumi, B.M., Nyirenda, S.P.M., Sileshi, G.W., Sola, P., Kamanula, J.F., Belmain, S.R. \& Stevenson, P.C., (2011), Pesticidal effects of indigenous plants extracts against rape aphids and tomato red spider mites. African Crop Science Conference Proceedings, Vol.10. pp. $169-171$.

Peyvastegan, S. and Farahbakhsh, A. (2011). The Residual Effects of Different Doses of Atrazine+Alachlor and Foramsulfuron on the Growth and Physiology of Rapeseed (Brassica napus L.) World Academy of Science, Engineering and Technology 50.

Reinhardt, C. F. (1995). Residual effect of atrazine on field-grown dry beans and sunflower, South African Journal of Plant and Soil, Volume 12, Issue 2: 82-85.

Rugare, J. T. (2009).An evaluation on the efficacy and economic feasibility of manual and chemical weed control strategies under smallholder conservation agriculture in Zimababwe's Highveld areas. In 
Crop Science, Vol. Master of Science: University of Zimbabwe

Süzer, S. and Büyük, H. (2010). Residual effects of spraying Imidazolinone-family herbicides on Clearfield sunflower production from the point of view of crop rotation, HELIA, 33, Nr. 52, p.p. 25-36.

Taber, H. G. (2009). Residual Effects of Callisto, Impact, and Laudis Herbicide on Cucumber, Pepper, Snap Bean, and Tomato Department of Horticulture lowa State University.

Thierfelder, C. and Wall, P. C. (2009). Effects of conservation agriculture techniques on infiltration and soil water content in Zambia and Zimbabwe. Soil and Tillage Research 105(2): 217-227.

Verma, V. K.; Tewari, A. N.; Dhemri, S. (2009). Effect of atrazine on weed management in winter maizegreengram cropping system in central plain zone of Uttar Pradesh, Indian Journal of Weed Science 2009 Vol. 41 No. 1/2 pp. 41-45

Vogel, H. (1994). The need for integrated weed management systems in smallholder conservation farming in Zimbabwe. 96: 35-36.

Wall, P. C. (2007). Tailoring conservation agriculture to the needs of small farmers in developing countries: An analysis of issues. Journal of Crop Improvement 19(1/2).

Cite this Article: Mutsvandiani C, Tembo L, Kurangwa W, 2015. The effect of Herbicides on Residual Effects of Atrazine under Conservation Agriculture. Greener Journal of Agricultural Sciences, 5(2): 062-075, http://doi.org/10.15580/GJAS.2015.2.082914341.

\section{APPENDICES}

Appendix i. Cowpea germination percentage_ha

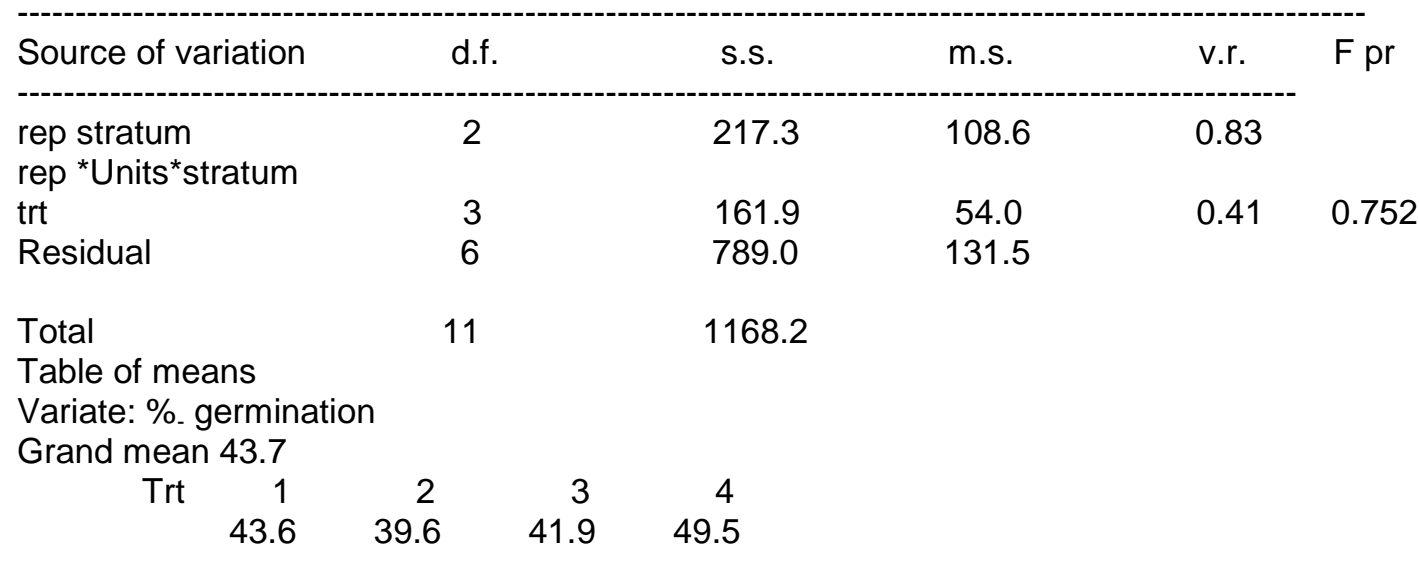

Standard error of means

Table

trt

rep

3

d.f.

6

e.s.e.

6.62

Standard error of difference of means

$\begin{array}{lr}\text { Table } & \text { trt } \\ \text { rep } & 3 \\ \text { d.f. } & 6 \\ \text { s.e.d. } & 9.36\end{array}$

Least significant difference of means ( $5 \%$ level)

Table trt

rep 3

d.f. 6

l.s.d. $\quad 22.91$ 
.Variate: Length_cm

\begin{tabular}{|c|c|c|c|c|c|}
\hline Source of variation & d.f. & & s.s. & m.s. & v.r. \\
\hline $\begin{array}{l}\text { rep stratum } \\
\text { rep *Units*stratum }\end{array}$ & 2 & & $0 . .2450$ & 0.1225 & 0.76 \\
\hline trt & 3 & & 2.4558 & 0.8186 & 5.11 \\
\hline Residual & 6 & & 0.9617 & 0.1603 & \\
\hline $\begin{array}{l}\text { Total } \\
\text { Table of means } \\
\text { Variate: Length_cm } \\
\text { Grand mean 16.37 }\end{array}$ & 11 & & 3.6625 & & \\
\hline $\begin{array}{lr}\text { Trt } & 1 \\
& 17.03\end{array}$ & $\begin{array}{r}2 \\
15.77\end{array}$ & $\begin{array}{r}3 \\
16.27\end{array}$ & $\begin{array}{r}4 \\
16.43\end{array}$ & & \\
\hline
\end{tabular}

Standard error of means

$\begin{array}{lr}\text { Table } & \text { trt } \\ \text { rep } & 3 \\ \text { d.f. } & 6 \\ \text { e.s.e. } & 6.62\end{array}$

Standard error of difference of means

$\begin{array}{lr}\text { Table } & \text { trt } \\ \text { rep } & 3 \\ \text { d.f. } & 6\end{array}$

s.e.d. $\quad 0.327$

Least significant difference of means ( $5 \%$ level)

Table trt

rep 3

d.f. 6

l.s.d. $\quad 0.800$

Appendix iii. Weed fresh weight_kg_ha

.Variate: Weed fresh weight_kg

\begin{tabular}{|c|c|c|c|c|c|}
\hline Source of variation & d.f. & s.s. & m.s. & v.r. & $\mathrm{F} \mathrm{pr}$ \\
\hline \multicolumn{6}{|l|}{ Rep stratum } \\
\hline $\begin{array}{l}\text { Treatment } \\
\text { Rep. *Units* stratum }\end{array}$ & \multirow{2}{*}{\multicolumn{3}{|c|}{ Rep. *Units* stratum }} & & \\
\hline Treatment & 3 & 2616.5 & 872.0 & 1.07 & \\
\hline Residual & 5 & 4078.7 & 815.7 & & \\
\hline Total & 11 & 7775.4 & & & \\
\hline \multicolumn{6}{|c|}{ 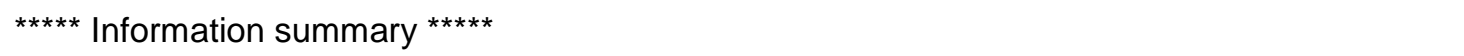 } \\
\hline \multirow{2}{*}{\multicolumn{2}{|c|}{ Rep stratum }} & \multirow{2}{*}{\multicolumn{4}{|c|}{ non-orthogonal terms }} \\
\hline & & & & & \\
\hline \multicolumn{6}{|l|}{ Rep. *Units* stratum } \\
\hline Treatment & 0.889 & $\operatorname{Rep}$ & & & \\
\hline
\end{tabular}

*Message the following units have large residuals.

$\begin{array}{llll}\text { Rep } 2 & \text { *units* } 2 & 40.8 & \text { s.e. } 18.4\end{array}$

*****Table of means $s^{* \star * * *}$

Variate: Weed fresh biomass_kg

Grand mean 26.4

Treatment

$\begin{array}{rrrr}1 & 2 & 3 & 4 \\ 30.3 & 35.7 & 21.8 & 17.8\end{array}$


${ }^{* * *}$ Standard error of means ${ }^{* * *}$

$\begin{array}{lr}\text { Table } & \text { Treatment } \\ \text { rep } & 3 \\ \text { d.f. } & 5 \\ \text { e.s.e. } & 17.49\end{array}$

*** Standard error of difference of means ***

Table Treatment

rep 3

d.f. 5

s.e.d. 24.73

*** Least significant difference of means ( $5 \%$ level) ***

Table

rep

Treatment

d.f.

3

I.s.d.

63.58

Appendix iv. Weed dry weight_kg_ha

.Variate: Weed dry biomass_kg

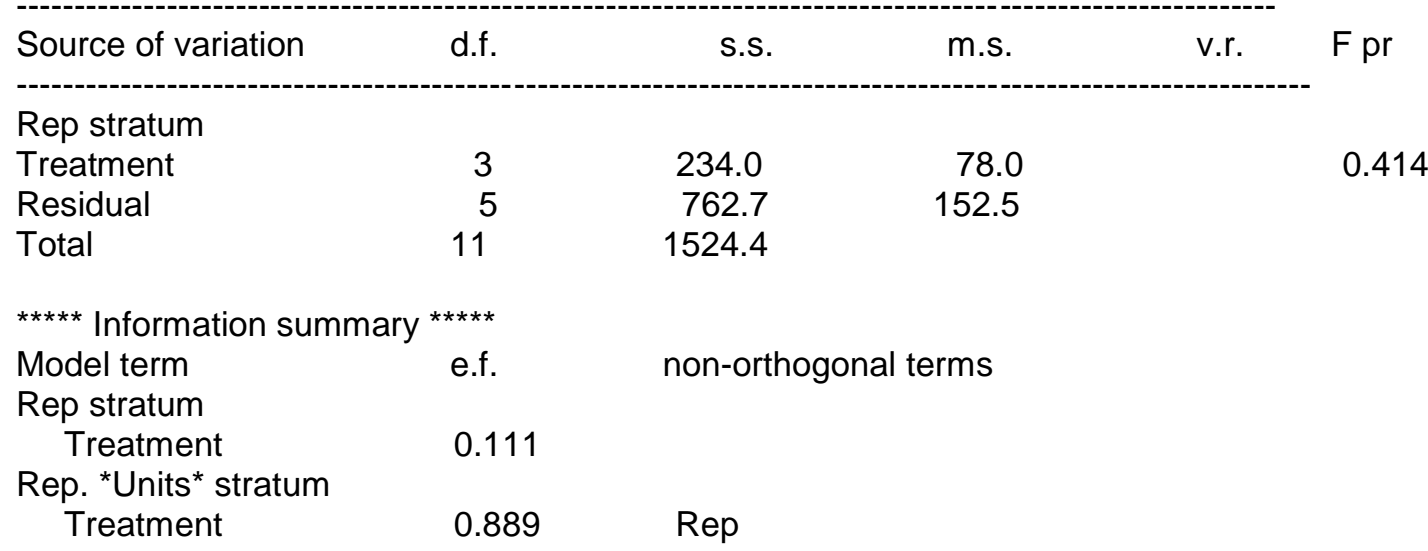

*Message the following units have large residuals.

$\begin{array}{llll}\text { Rep } 2 & \text { *inits* } 2 & 17.2 & \text { s.e. 8.0. }\end{array}$

*****Table of means ${ }^{* \star * * *}$

Variate: Weed dry biomass_kg

Grand mean 26.4

Treatment

$\begin{array}{rrrr}1 & 2 & 3 & 4 \\ 30.3 & 35.7 & 21.8 & 17.8\end{array}$

*** Standard error of means ${ }^{* * *}$

Table

rep

Treatment

d.f.

3

e.s.e.

7.56

*** Standard error of difference of means ***

Table

rep

Treatment

d.f.

3

s.e.d.

27.49

*** Least significant difference of means ( $5 \%$ level) $* * *$

Table

rep

Treatment

d.f.

3

I.s.d.

27.49 
Appendix v. Cowpea fresh biomass_kg_ha week 1

.Variate: Cowpea fresh biomass_kg

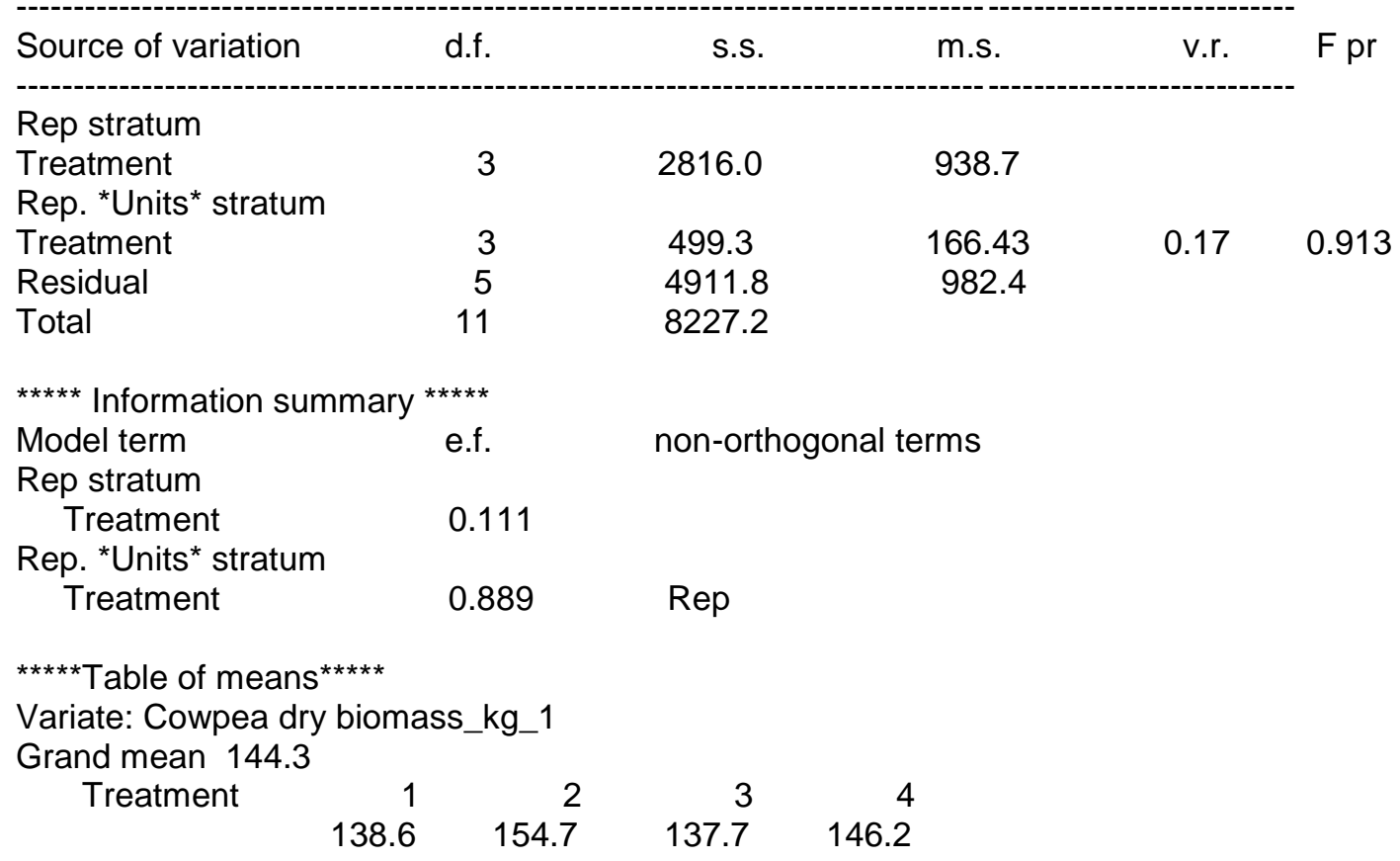

***Standard error of means ${ }^{* * *}$

Table

rep

Treatment

d.f.

3

e.s.e.

19.19

*** Standard error of difference of means ***

Table

rep

Treatment

d.f.

3

s.e.d.

27.14

*** Least significant difference of means $\left(5 \%\right.$ level) ${ }^{* * *}$

Table

rep

Treatment

d.f.

3

I.s.d.

69.77

Appendix vi. Cowpea dry biomass_kg_ha week 2

.Variate: Cowpea dry biomass_kg

\begin{tabular}{|c|c|c|c|c|}
\hline Source of variation & d.f. & s.s. & m.s. & v.r. \\
\hline \multicolumn{5}{|l|}{ Rep stratum } \\
\hline $\begin{array}{l}\text { Treatment } \\
\text { Rep. *Units }{ }^{*} \text { stratum }\end{array}$ & \multicolumn{4}{|c|}{ Rep. *Units ${ }^{*}$ stratum } \\
\hline Treatment & 3 & 24050 . & 8017. & \multirow[t]{3}{*}{0.62} \\
\hline Residual & 5 & 64267. & 12853. & \\
\hline Total & 11 & 142264. & & \\
\hline \multicolumn{5}{|c|}{ ***** Information summary $* * * * *$} \\
\hline Model term & e.f. & \multicolumn{3}{|c|}{ non-orthogonal terms } \\
\hline \multicolumn{5}{|l|}{ Rep stratum } \\
\hline \multirow{2}{*}{\multicolumn{5}{|c|}{$\begin{array}{l}\text { Treatment } \\
\text { Rep. *Units* stratum }\end{array}$}} \\
\hline & & & & \\
\hline Treatment & 0.889 & Rep & & \\
\hline
\end{tabular}


$\star * * * *$ Table of means ${ }^{* * * *}$

Variate: Cowpea fresh biomass_kg_ha

Grand mean 45.3

$\begin{array}{crrrr}\text { Treatment } & 1 & 2 & 3 & 4 \\ & 387 . & 520 . & 462 . & 443 .\end{array}$

*** Standard error of means ${ }^{* * *}$

$\begin{array}{lc}\text { Table } & \text { Treatment } \\ \text { rep } & 3 \\ \text { d.f. } & 5 \\ \text { e.s.e. } & 69.4\end{array}$

*** Standard error of difference of means ***

Table Treatment

rep

d.f.

s.e.d.

98.2

*** Least significant difference of means ( $5 \%$ level) ***

Table Treatment

rep 3

d.f. 5

l.s.d. $\quad 252.4$

Appendix vi. Cowpea dry biomass_kg_ha week 3

Variate: Cowpea dry biomass_kg_ha

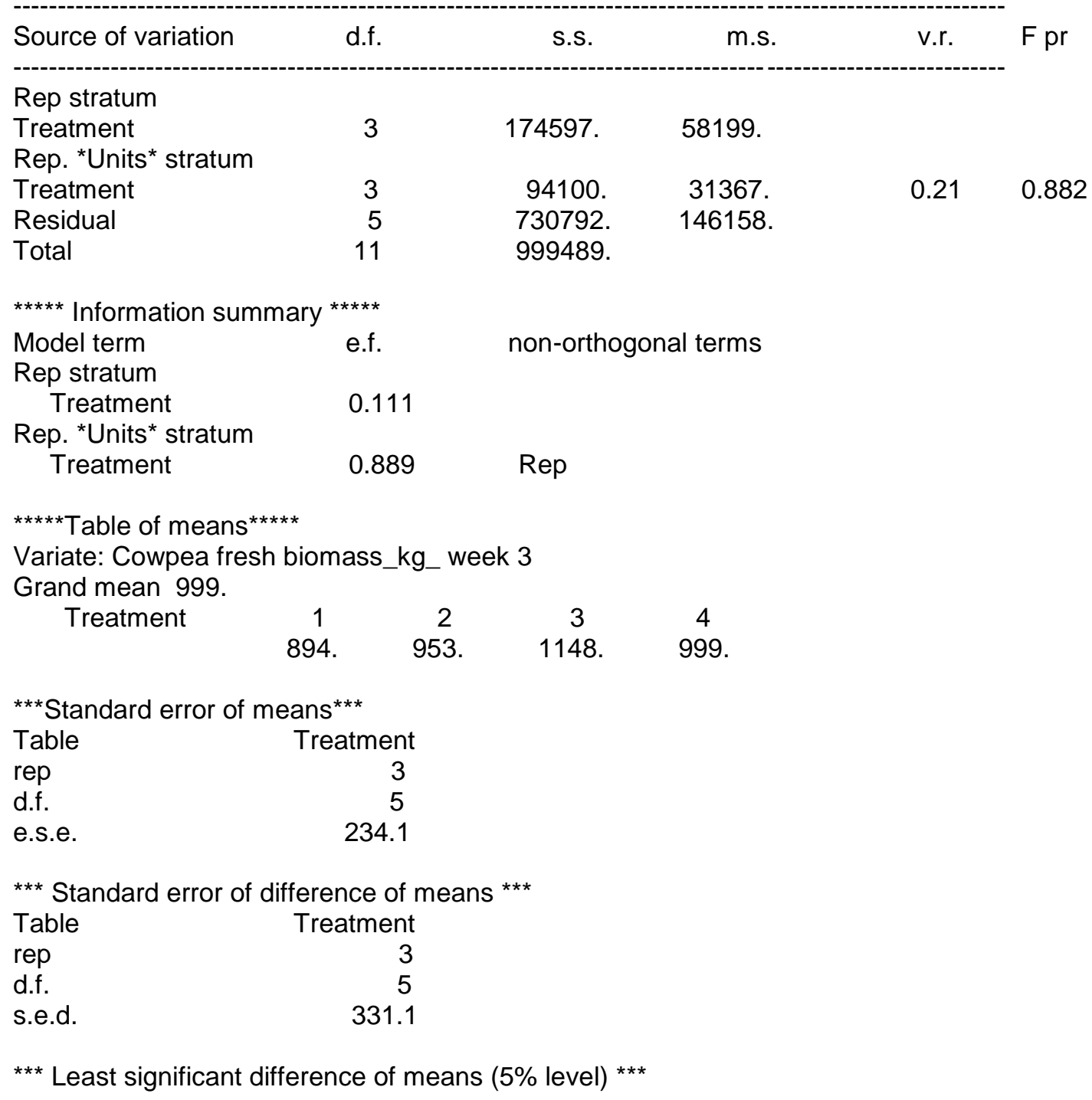


Table

rep

d.f.

l.s.d.
Treatment

3

851.1

Appendix vi. Cowpea dry biomass_kg week 1

.Variate: Cowpea dry biomass_kg_ha

\begin{tabular}{|c|c|c|c|c|c|}
\hline Source of variation & d.f. & s.s. & m.s. & v.r. & $\mathrm{F} \mathrm{pr}$ \\
\hline \multicolumn{6}{|l|}{ Rep stratum } \\
\hline Treatment & 3 & 32.73 & 10.91 & & \\
\hline \multicolumn{6}{|l|}{ Rep. *Units* stratum } \\
\hline Treatment & 3 & 9.93 & 3.31 & 0.23 & 0.875 \\
\hline Residual & 5 & 73.47 & 14.69 & & \\
\hline Total & 11 & 116.14 & & & \\
\hline \multicolumn{5}{|c|}{${ }_{* * * * *}^{\text {Information summary }}$ *****} & \\
\hline Model term & e.f. & \multicolumn{3}{|c|}{ non-orthogonal terms } & \\
\hline \multicolumn{5}{|l|}{ Rep stratum } & \\
\hline Treatment & 0.111 & & & & \\
\hline \multicolumn{5}{|l|}{ Rep. *Units* stratum } & \\
\hline Treatment & 0.889 & Rep & & & \\
\hline
\end{tabular}

*MESSAGE: the following units have large residuals.

$\begin{array}{llll}\text { Rep } 2{ }^{*} \text { units }^{*} 2 & -5.0 & \text { s.e. } & 2.5\end{array}$

*****Table of means $s^{* * * *}$

Variate: Cowpea dry biomass_kg_ha week 1

Grand mean 16.1

Treatment

$\begin{array}{rrrr}1 & 2 & 3 & 4 \\ 14.5 & 17.1 & 16.4 & 16.5\end{array}$

${ }^{* * *}$ Standard error of means ${ }^{* * *}$

$\begin{array}{lr}\text { Table } & \text { Treatment } \\ \text { rep } & 3 \\ \text { d.f. } & 5 \\ \text { e.s.e. } & 2.35\end{array}$

*** Standard error of difference of means ${ }^{* * *}$

Table Treatment

rep 3

d.f. 5

s.e.d. $\quad 3.32$

*** Least significant difference of means ( $5 \%$ level) $* * *$

Table Treatment

rep 3

d.f. $\quad 5$

l.s.d. $\quad 8.53$

Appendix viii. Cowpea dry biomass_kg_ha week 2

.Variate: Cowpea dry biomass_kg

\begin{tabular}{|c|c|c|c|c|}
\hline Source of variation & d.f. & s.s. & m.s. & v.r. \\
\hline $\begin{array}{l}\text { Rep stratum } \\
\text { Treatment } \\
\text { Rep. *Units* stratum }\end{array}$ & 3 & 474.9 & 158.3 & \\
\hline
\end{tabular}




$\begin{array}{lccccc}\text { Treatment } & 3 & 319.2 & 106.4 & 0.55 & 0.669 \\ \text { Residual } & 5 & 965.3 & 193.1 & & \\ \text { Total } & 11 & 1759.3 & & & \end{array}$

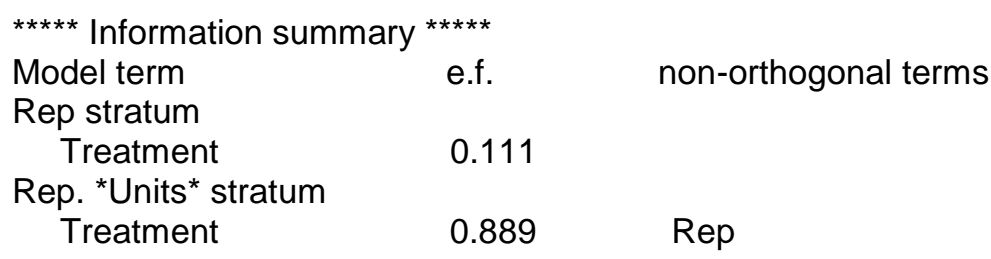

*****Table of means $s^{* * * *}$

Variate: Cowpea dry biomass_kg_ha week 2

Grand mean 16.1

Treatment

$\begin{array}{rrrr}1 & 2 & 3 & 4 \\ 54.9 & 69.9 & 64.4 & 60.5\end{array}$

*** Standard error of means ${ }^{* * *}$

Table Treatment

rep 3

d.f. 5

e.s.e. $\quad 8.51$

*** Standard error of difference of means ${ }^{* * *}$

Table Treatment

$\begin{array}{ll}\text { rep } & 3 \\ \text { dff } & 5\end{array}$

$\begin{array}{lr}\text { d.f. } & 12.3 \\ \text { s.e.d. } & \end{array}$

${ }^{* * *}$ Least significant difference of means $\left(5 \%\right.$ level) ${ }^{* * *}$

Table Treatment

rep 3

d.f. 5

l.s.d. $\quad 30.93$

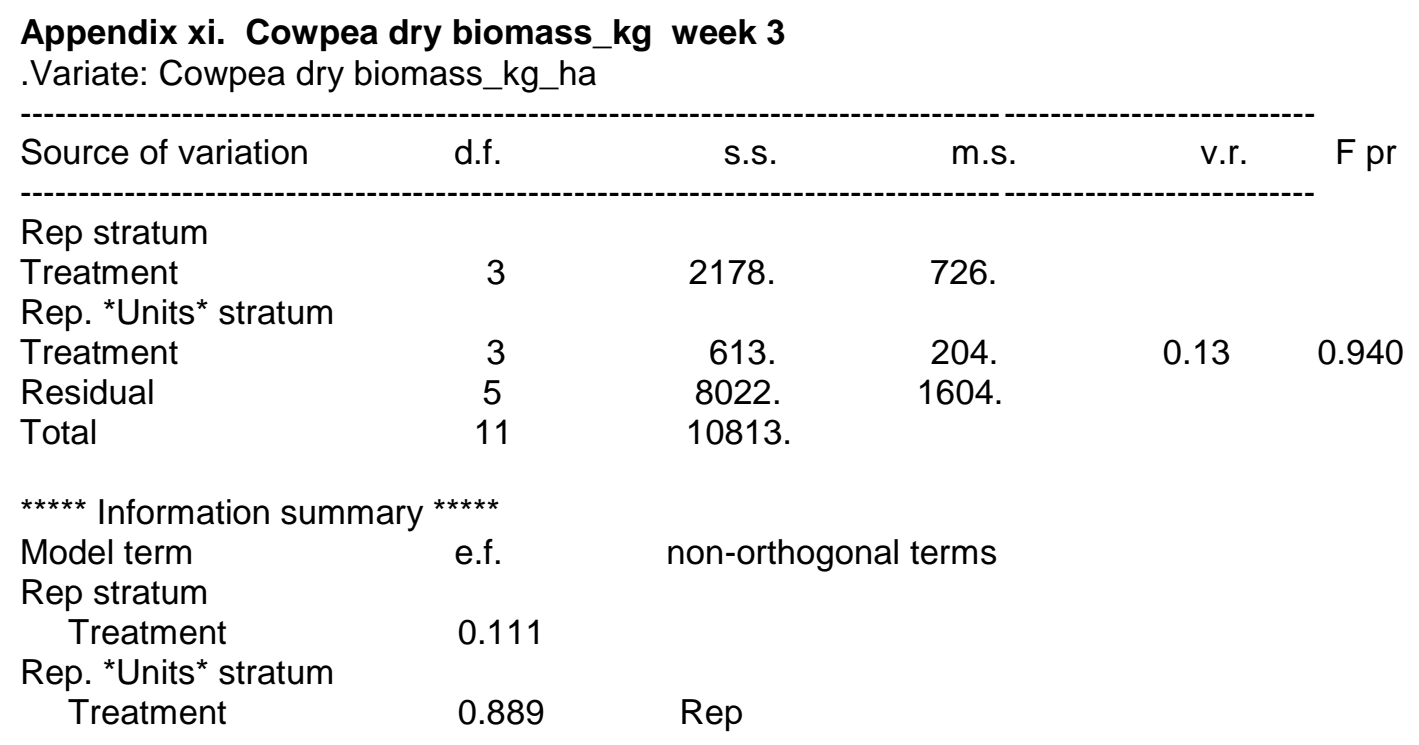

*****Table of means $s^{* * * *}$

Variate: Cowpea dry biomass_kg_ha week 3

Grand mean 171.

$\begin{array}{lrrrr}\text { Treatment } & 1 & 2 & 3 & 4\end{array}$

163. 183.171 .166$.

${ }^{* * *}$ Standard error of means ${ }^{* * *}$ 


$\begin{array}{lr}\text { Table } & \text { Treatment } \\ \text { rep } & 3 \\ \text { d.f. } & 5 \\ \text { e.s.e. } & 8.51\end{array}$

*** Standard error of difference of means ***

Table Treatment

rep

d.f.

s.e.d.

24.5

*** Least significant difference of means ( $5 \%$ level) $* * *$

Table Treatment

rep

d.f.

l.s.d.

3

89.2

Appendix x. Cowpea yield_kg

.Variate: Cowpea yield_kg_ha

\begin{tabular}{lrrrrr} 
Source of variation & d.f. & s.s. & m.s. & v.r. & F pr \\
\hdashline Rep stratum & 2 & 13522. & 6761. & 1.37 & \\
$\begin{array}{l}\text { Rep. }{ }^{*} \text { Units } \\
\text { Treatment }\end{array}$ & 3 & 130973. & 43658. & \multirow{2}{*}{8.82} & \multirow{2}{*}{0.013} \\
Residual & 6 & 29698. & 4950. & & \\
Total & 11 & 174193. & & &
\end{tabular}

***** Table of means $s^{* \star * * *}$

Variate: Cowpea yield_kg

Grand mean 1066.

$\begin{array}{crrrr}\text { Treatment } & 1 & 2 & 3 & 4 \\ & 163 & 183 & 171 . & 166 .\end{array}$

*** Standard error of means ${ }^{* * *}$

$\begin{array}{lr}\text { Table } & \text { Treatment } \\ \text { rep } & 3 \\ \text { d.f. } & 5 \\ \text { e.s.e. } & 40.6\end{array}$

*** Standard error of difference of means ${ }^{* * *}$

Table

rep

Treatment

d.f.

3

s.e.d.

57.4

Stratum errors and coefficients of variation $* * \star * \star$

.Variate: Cowpea yield_kg_ha

\begin{tabular}{|c|c|c|c|}
\hline d.f. & s.e. & c.v \% & \\
\hline Rep & 2 & 41.1. & 3.9 \\
\hline \multicolumn{4}{|c|}{${ }^{* * *}$ Least significant difference of means ( $5 \%$ level) ${ }^{* * *}$} \\
\hline \multicolumn{4}{|c|}{ Table $\quad$ Treatment } \\
\hline rep & 3 & & \\
\hline d.f. & 6 & & \\
\hline I.s.d. & 140.6 & & \\
\hline
\end{tabular}

